\title{
DEVELOP AN EMPOWERMENT MODEL FOR POOR FARMERS IN JENEPONTO, SOUTH SULAWESI
}

\author{
Saparuddin M \\ Dosen Fakultas Ekonomi, Universitas Negeri Jakarta \\ saparuddin@feunj.ac.id
}

\begin{abstract}
The objective of this study is to develop an empowerment model for poor farmers in Jeneponto, South Sulawesi. This study used descriptive method, with three approaches, economics, social and cultural, and institutional approach. Results of this study are: 1) the farmers in Jeneponto have limited knowledge of modern agriculture. 2) most of poor farmers in Jeneponto was not caused by the condition of natural resources. 3) some of agriculture comoditions could enhance optimally with good water management system. 4) low rate of savings caused the low rate investation and productivity.
\end{abstract}

Key words: farmer empowerment, poverty 


\section{PENDAHULUAN}

Peran strategis pertanian tersebut digambarkan melalui kontribusi yang nyata melalui pembentukan kapital; penyedia bahan pangan; bahan baku industri; pakan dan bioenergi, penyerap tenaga kerja, sumber devisa negara, sumber pendapatan, serta pelestarian lingkungan melalui praktek usahatani yang ramah lingkungan. Berbagai peran strategis pertanian dimaksud sejalan dengan tujuan pembangunan perekonomian nasional yaitu: (1) meningkatkan kesejahteraan masyarakat; (2) mempercepat pertumbuhan ekonomi, kemiskinan;

(3) menyediakan lapangan kerja; (4) memelihara keseimbangan sumberdaya alam dan lingkungan hidup (Bappenas, 2010).

Kabupaten

Jeneponto mempunyai luas wilayah $749,79 \mathrm{~km}^{2}$ dengan jumlah penduduk 331.938 jiwa. Berdasarkan jenis penggunaan tanah (Land Use) maka penggunaan tanah terluas adalah tegalan/kebun yaitu tercatat $34.154,14$ ha $(45,56 \%)$, persawahan $20.014,08$ ha $(26,69$ $\%)$, hutan negara tercatat $9.842,65$ ha $(13,12 \%)$ (Anonim, 2006). Beberapa komoditas yang dominan dan mempunyai peluang untuk dikembangkan melalui; inovasi teknologi, kelembagaan dan pemanfaatan sumberdaya lahan antara lain; padi, jagung, ubi kayu, kacang kedelai, dan buah-buahan.
Pada sub sektor peternakan, yaitu kuda, kambing, sapi, ayam ras, ayam kampung dan itik. Hasil penelitian Unhas (2006) menunjukkan bahwa dari 16 komoditas yang dikembangkan petani, ada lima komoditas yang memiliki areal pengembangan di atas 2000 ha, yaitu padi, jagung, ubi kayu, kedelai, dan mangga. Dari lima komoditas jagung memiliki areal terluas (27.342 ha), kemudian padi (14.232 ha), mangga (12.148 ha), dan ubi kayu (5.508 ha), dengan potensi yang besar tersebut, masyarakat petani di Kabupaten Jeneponto masih dalam taraf kehidupan yang masih rendah/miskin.

Kelurahan Tolo Utara, Kecamatan Kelara, Kabupaten Jeneponto sebagai wilayah MP3MI, sebagian besar wilayahnya adalah lahan kering dengan luas 759,65 ha, termasuk dalam sub agroekosistem Lahan Kering Dataran Rendah Iklim Kering (LKDRIK). Pemanfaatan lahan dikelompokan menjadi 3 satuan penggunaan lahan, yaitu: sawah 57,57 ha $(7,58 \%)$, tegalan 650,61 ha $(85,65 \%)$, dan pemukiman 51,47 ha $(6,78 \%)$. Sistem pertanaman monokultur jagung dengan tanaman sisipan ubi kayu dan kacang-kacangan. Pola tanam yang berlaku yaitu jagung-ubikayu, jagung atau kapas. Penduduk Kelurahan Tolo Utara sebanyak 3.519 jiwa, atau $13,4 \%$ dari jumlah penduduk Kecamatan Kelara yang mencapai 26.358 jiwa 
(BPS, 2014). Komoditas pertanian yang banyak diusahakan adalah; jagung, ubi kayu dan sayuran (Cabai dan Kacang2an). Produktivitas lahan yang dicapai masih rendah (jagung 4,5 t/ha), oleh karena itu untuk meningkatkan produktivitas lahan, diperlukan adanya transformasi pertanian sistem pertanian dari yang berbasis sumberdaya lahan (hanya mengandalkan kemurahan lahan) ke sistem pertanian yang berbasis ilmu pengetahuan dan teknologi. Dengan transformasi tersebut diharapkan produktivitas pertanian dan kesejahteraan petani dapat ditingkatkan, kelestarian sumberdaya lahan juga tetap terjaga.

Kabupaten Jeneponto merupakan kabupaten yang paling tertinggal dan tingkat kemiskinan paling tinggi kedua di Provinsi Sulawesi Selatan, hal inilah yang menjadi fokus penelitian ini.

\section{Rumusan Masalah}

Masalah yang akan dikaji dalam penelitian ini adalah "Pemberdayaan masyarakat petani miskin di Kabupaten Jeneponto Provinsi Sulawesi Selatan"

\section{Maksud dan Tujuan Penelitian}

Maksud dan tujuan dari kegiatan penelitian ini adalah untuk : 1) menganalisis bagaimana pemberdayaan masyarakat petani miskin di Kabupaten Jeneponto Provinsi Sulawei Selatan, 2) memberikan masukan penting ke Pemerintah Daerah terkait dengan solusi pengentasan masyarakat petani miskin di Kabupaten Jeneponto.

\section{KAJIAN PUSTAKA Indikator Kemiskinan Berdasarkan Dimensi Ekonomi}

Berdasarkan sudut pandang ekonomi, kemiskinan adalah bentuk ketidakmampuan dari pendapatan seseorang maupun sekelompok orang untuk mencukupi kebutuhan pokok atau kebutuhan dasar. Dimensi ekonomi dari kemiskinan diartikan sebagai kekurangan sumber daya yang dapat digunakan atau dimanfaatkan untuk meningkatkan taraf kesejahteraan seseorang baik secara finansial maupun jenis kekayaan lainnya yang dapat digunakan untuk meningkatkan kesejahteraan masyarakat (Suryawati, 2004: 123). Dari pengertian ini, dimensi ekonomi untuk kemiskinan memiliki dua aspek, yaitu aspek pendapatan dan aspek konsumsi atau pengeluaran. Aspek pendapatan yang dapat dijadikan sebagai indikator kemiskinan adalah pendapatan per kapita, sedangkan untuk aspek konsumsi yang dapat digunakan sebagai indikator kemiskinan adalah garis kemiskinan. 1) Pendapatan Per Kapita 
Pendapatan per kapita menyatakan besarnya ratarata pendapatan masyarakat di suatu daerah selama kurun waktu 1 tahun. Besarnya pendapatan per kapita (income per capita) dihitung dari besarnya output dibagi oleh jumlah penduduk di suatu daerah untuk kurun waktu 1 tahun (Smith, 2003). Indikator pendapatan per kapita menerangkan terbentuknya pemerataan pendapatan yang merupakan salah satu indikasi terbentuknya kondisi yang disebut miskin. Pendapatan per kapita dapat dihitung dengan menggunakan rumus sebagai berikut (Smith, 2003)

2) Garis Kemiskinan

Garis kemiskinan merupakan salah satu indikator kemiskinan yang menyatakan rata-rata pengeluaran makanan dan non-makanan per kapita pada kelompok referensi (reference population) yang telah ditetapkan (BPS, 2004). Kelompok referensi ini didefinisikan sebagai penduduk kelas marjinal, yaitu mereka yang hidupnya dikategorikan berada sedikit di atas garis kemiskinan. Berdasarkan definisi dari BPS, garis kemiskinan dapat diartikan sebagai batas konsumsi minimum dari kelompok masyarakat marjinal yang berada pada referensi pendapatan sedikit lebih besar daripada pendapatan terendah. Pada prinsipnya, indikator garis kemiskinan mengukur kemampuan pendapatan dalam memenuhi kebutuhan pokok/dasar atau mengukur daya beli minimum masyarakat di suatu daerah. Konsumsi yang dimaksudkan dalam garis kemiskinan ini meliputi konsumsi untuk sandang, pangan, perumahan, kesehatan, dan pendidikan (Suryawati, 2004: 123).

Sementara Kotze (Hikmat, 2004) menyatakan bahwa masyarakat miskin memiliki kemampuan yang relatif baik untuk memperoleh sumber melalui kesempatan yang ada. Kendatipun bantuan luar kadang-kadang digunakan, tetapi tidak begitu saja dapat dipastikan sehingga masyarakat bergantung pada dukungan dari luar. Pendekatan pemberdayaan ini dianggap tidak berhasil karena tidak ada masyarakat yang dapat hidup dan berkembang bila terisolasi dari kelompok masyarakat lainnya. Pengisolasian ini menimbulkan sikap pasif, bahkan keadaan menjadi semakin miskin.

$$
\text { Selanjutnya Supriatna }
$$
(1997:90) menyatakan bahwa kemiskinan adalah situasi yang serba terbatas yang terjadi bukan atas kehendak orang yang bersangkutan. Suatu penduduk dikatakan miskin bila ditandai oleh 
rendahnya tingkat pendidikan, produktivitas kerja, pendapatan, kesehatan dan gizi serta kesejahteraan hidupnya, yang menunjukkan lingkaran ketidakberdayaan. Kemiskinan bisa disebabkan oleh terbatasnya sumber daya manusia yang ada, baik lewat jalur pendidikan formal maupun nonformal yang pada akhirnya menimbulkan konsekuensi terhadap rendahnya pendidikan informal.

Bank Dunia (1990) dalam laporannya di hadapan anggota PBB bertitel "Poverty and Human Development' mengatakan bahwa: "The case for human developemnt is not only or even primarily an economic one. Less hunger, fewer child death, and better change of primary education are almost universally accepted as important ends in themselves" (pembangunan manusia tidak hanya diutamakan pada aspek ekonomi, tapi yang lebih penting ialah mengutamakan aspek pendidikan secara universal bagi kepentingan diri orang miskin guna meningkatkan kehidupan sosial ekonominya).

$$
\text { Booth dan Me Cawley }
$$
(Dalam Moeljarto T., 1993) menyatakan bahwa "di banyak negara memang terjadi kenaikan tingkat kesejahteraan masyarakat yang diukur dari pendapatan perkapitanya, tetapi itu hanya dapat dinikmati oleh sebagian kecil masyarakatnya, sedangkan sebagian besar masyarakat miskin kurang memperoleh manfaat apaapa, bahkan sangat dirugikan".

Kriteria lain tentang pendudukan miskin berkenaan dengan implementasi Program Pengembangan Kecamatan (PPK) menurut versi Badan Koordinasi Keluarga Berencana Nasional (BKKBN), bahwa untuk menentukan penduduk miskin paling tidak memenuhi 6 (enam) kriteria sebagai berikut:

1. Rumah layak huni: a) milik sendiri dan b) bukan milik sendiri.

2. Akses air bersih dan sanitasi

3. Pendapatan/dikonversi dengan pengeluaran

4. Kepemilikan aset

5. Frekuensi makan (lebih dari 2 kali sehari) dan kualitas gizi makanan

6. Dalam setahun dapat membeli minimal 1 stel pakaian baru.

Berkenaan dengan strategi pemberdayaan, Mark G. Hanna dan Buddy Robinson (Hikmat, 2004) mengemukan bahwa ada tiga strategi utama pemberdayaan dalam praktek perubahan sosial, yaitu tradisional, direct action (aksi langsung), dan transformasi. 1) Strategi tradisional, menyarankan agar mengetahui dan memilih kepentingan terbaik secara bebas dalam berbagai keadaan, 2) Strategi direct-action, membutuhkan dominasi kepentingan yang dihormati oleh semua pihak yang terlibat, dipandang dari sudut perubahan 
yang mungkin terjadi, dan 3) Strategi transformatif, menunjukkan bahwa pendidikan massa dalam jangka panjang dibutuhkan sebelum pengidentifikasian kepentingan diri sendiri.

Dengan demikian menurut Hikmat (Hikmat, 2004) bahwa proses pembangunan masyarakat hendaknya diasumsikan pada prinsip-prinsip sebagai berikut:

a) Arah pertumbuhan masyarakat selalu bertumpu pada semakin membesarnya partisipasi dalam struktur sosial.

b) Terjadinya berbagai kondisi ketidakpuasan yang dirasakan oleh warga masyarakat dewasa ini harus dijadikan sebagai titik tolak bagi program pembangunan masyarakat.

c) Ketidakpuasan yang dirasakan dan dialami oleh warga masyarakat harus disalurkan kedalam perencanaan dan tindakan pemecahan masalah bersama.

d) Pelaksanaan program-program pembangunan masyarakat harus mengikutsertakan pemimpinpemimpin yang diidentifikasikan dan diterima oleh berbagai kelompok sosial utama dalam masyarakat.

e) Organisasi pelaksana program pembangunan masyarakat harus mengembangkan jalur komunikasi yang efektif-efisien dalam berbagai kelompok sosial utama masyarakat, serta memperkuat kemampuan kelompok itu untuk saling bekerjasama melaksanakan prosedur kerja yang luwesfleksibel, tanpa merusak pola pengambilan keputusan (decision making) secara teratur.

f) Penentuan program pembangunan masyarakat harus bertumpu pada keputusan bersama warga masyarakat itu sendiri, dengan memperhatikan kecepatan langkah masyarakat dan melibatkan warga masyarakat secara penuh dalam proses perencanan pembangunan.

Mengapa pula pembangunan masyarakat dipandang sangat penting, Hikmat (Hikmat, 2004) mengemukakan pertimbanganpertimbangannya sebagai berikut:

1. Masyarakat yang sehat merupakan produk dari masyarakat yang aktif.

2. Proses perencanaan yang berasal dan diinginkan oleh masyarakat adalah lebih baik dibandingkan dengan perencanaan yang berasalh dari penguasa.

3. Proses partisipasi dalam pembangunan masyarakat merupakan pencegahan berbagai sikap masa bodoh dari individuindividu dalam masyarakat.

4. Proses pemberdayaan yang kuat dalam upaya-upaya kemasyarakatan merupakan dasar kekuatan bagi masyarakat. 
Faktor Penentu Kemiskinan Di Indonesia, adalah : a. Tingkat Pendidikan Yang Ditamatkan Penduduk (EDU), b. Pendapatan Per kapita Penduduk (PC), c. Rasio Ketergantungan Penduduk, d. Pertumbuhan Ekonomi (GRW), e. Persentase Tenaga Kerja Di Sektor Pertanian (TKP), f. Persentase Tenaga Kerja Disektor Industri (TKI).

\section{METODE PENELITIAN}

Penelitian ini bertujuan untuk mengembangkan model pemberdayaan petani miskin di Kabupaten Jeneponto, Penelitian ini akan dilakukan dengan menggunakan metode deksriptif.

Jangka waktu penelitian ini selama enam bulan. Fokus penelitian untuk mengembangkan model pemberdayaan petani miskin di Kabupaten Jeneponto. Penelitian ini dilakukan dengan tahapan sebagai berikut:

1. Studi literatur untuk menentukan metode pemberdayaan petani miskin

2. Melakukan klarifikasi kriteria yang akan digunakan dengan melakukan:

a. In-depth interview (IDI) dengan perwakilan pihak petani dan ketua kelompok tani di beberapa kecamatan, wawancara dengan Dinas Pertanian Kabupaten Jeneponto

b. Focus Group Discussion (FGD) dengan pihak petani, kelompok tani, dan dinas pertanian di Kabupaten Jeneponto.

3. Mengembangkan model pengambilan keputusan dengan menggunakan metode SWOT

4. Melakukan pengambilan data sekunder terkait dengan petani miskin di Kabupaten Jeneponto

5. Melakukan analisis data untuk menentukan model pemberdayaan petani miskin di Kabupaten Jeneponto.

Observasi yang telah dilakukan secara umum diarahkan untuk memperoleh masukan bagi penyempurnaan program pemberdayaan petani di daerah tertinggal/terisolir untuk meningkatkan kesejahteraan. Berkenaan dengan itu, beberapa langkah pengamatan yang diterapkan antara lain adalah:

1. Mengamati perkembangan Program Pemberdayaan Petani Miskin di Kabupaten Jeneponto, Provinsi Sulawesi Selatan.

2. Memperoleh informasi tentang kondisi kemiskinan masyarakat petani miskin di daerah tertinggal/terisolir, khususnya di Kabupaten Jeneponto, Provinsi Sulawesi Selatan.

3. Mengetahui faktor-faktor penyebab kemiskinan dan upaya untuk meningkatkan kesejahteraan petani, di Kabupaten Jeneponto, Provinsi Sulawesi Selatan.

4. Mengidentifikasi potensi 
sumberdaya yang dapat dioptimalkan bagi peningkatan kesejahteraan petani sebagai solusi dalam menekan kemiskinan di daerah tersebut.

Dalam observasi deskriptif ini diterapkan tiga pendekatan yakni Pertama, pendekatan ekonomi untuk mengamati perkembangan penghasilan dan produksi petani. Kedua, pendekatan sosial-budaya digunakan dalam kaitan dukungan aspek-aspek kemasyarakatan dalam implementasi program pemberdayaan petani. Ketiga, pendekatan kelembagaan untuk mengamati peran dan fungsi kelembagaan sejalan dengan tujuan program pemberdayaan.

Lokasi observasi ditentukan secara sengaja (Purposive sampling technique) mengingat program pemberdayaan hanya terdapat pada lokasi tertentu saja. Lokasi pengambilan sampel petani dimaksud adalah Desa Allu' Taroang dan Desa Ti'no yang berada di Kecamatan Batang, Kabupaten Jeneponto. Kedua desa tersebut termasuk dalam kategori desa tertinggal atau terisolasi yang memiliki permasalahan dalam hal transportasi dan komunikasi dengan desa atau tempat lain. Pada kedua desa tersebut dilakukan wawancara terhadap 30 orang petani, sebagai representasi komunitas petani miskin yang penghasilannya secara ekonomis tidak mencukupi untuk menutupi kebutuhan hidupnya (subsistence).

\section{HASIL PENELITIAN DAN PEMBAHASAN}

1. Implementasi Program Pemberdayaan Petani Miskin Program pemberdayaan petani miskin yang diterapkan oleh Departemen Pertanian dan dikelola melalui sistem BPLM. Tujuan sistem ini adalah untuk meningkatkan pendapatan masyarakat petani dengan jalan membantu petani dalam memproduksi komoditas pertanian tertentu. Dalam implementasinya BPLM diselenggarakan melalui PPA yang dikelola oleh Dinas Pertanian Kabupaten Jeneponto, dan PPKP dilaksanakan oleh Badan Ketahanan dan Penyuluhan Pangan Kabupaten Jeneponto. PPA diarahkan untuk komoditas Palawija dan Kapas sedangkan PPKP untuk komoditas tanaman Padi Sawah dan tegalan, (Kabupaten Jeneponto, 2013).

Penyusunan rencana pembangunan jangka menengah daerah (RPJMD) membutuhkan kerangka analisis isu-isu strategis yang didukung oleh kemampuan untuk menangkap setiap interaksi sosial, ekonomi, politik, budaya, dan teknologi. Ada beberapa hal yang mempengaruhi interaksi tersebut, antara lain situasi global, meliputi aspek-aspek yang terjadi melampaui batasbatas administrasi negara, situasi nasional, dan situasi regional. 
Keterkaitan antar isu strategis dimaksudkan dapat mendorong penguatan dan penerapan prioritisasi dalam perencanaan pembangunan daerah berdasarkan fakta-fakta. Karena itu, penyusunan rencana jangka menengah daerah yang dikonseptualisasi akan bergerak dari realitas dasar mencakup pembangunan di segala bidang diharapkan lebih dapat memperhatikan perkembangan realitas lain menyangkut keadaan yang menggambarkan penciptaan realitas dasar diantara arus eksternalisasi isu global mampu mempengaruhi dan merembesi isu regional dan isu daerah.

\section{Dinamika Lingkungan Strategis}

Kajian isu strategis mendasarkan pada situasi dan kondisi lingkungan strategis. Lingkungan strategis adalah lingkungan yang dapat mempengaruhi tingkat pencapaian tujuan pembangunan. Dinamika yang terjadi di dunia internasional, nasional, regional maupun lokal penting dipahami dan disikapi untuk tindakan kebijakan prefentif maupun kuratif. Kemajuan global makin meningkatkan keterkaitan pengaruh dunia internasional, terhadap kondisi nasional, regional maupun lokal. Hubungan antar manusia dengan segala kepentingan, aktivitas dan akibat atau kejadian-kejadiannya, melahirkan isu-isu dan permasalahan strategis baik positif maupun negatif.

\section{Lingkungan Internasional}

a. Globalisasi perdagangan dan jasa

Perdagangan bebas memperketat persaingan sektor usaha antar negara, sehingga dibutuhkan kualitas SDM (tenaga kerja) yang mampu menghasilkan produk-produk ekspor (barang dan jasa) yang unggul dan berdaya saing. Kekalahan daya saing akan berakibat pada penurunan ekspor serta kegagalan program penempatan tenaga kerja atau pengurangan pengangguran.

\section{b. Fluktuasi harga dan kurs mata uang}

Produktivitas yang tidak sebanding dengan tingginya konsumsi mencerminkan pola hidup konsumtif yang harus dikurangi. Besarnya konsumsi mempengaruhi daya saing rupiah terhadap mata uang internasional dan dalam keterkaitan dengan perdagangan internasional akan terjadi ketimpangan (defisit) Neraca Pembayaran. Fluktuasi negatif ataupun penurunan nilai rupiah yang signifikan mengakibatkan instabilitas APBN yang selanjutnya akan mengurangi besaran dana perimbangan (DAU, DAK dan lainnya).

c. Degradasi lingkungan 
Pemanasan global berdampak pada terjadinya pencairan es/salju yang menambah kenaikan permukaan air laut (rob). Akibat lainnya adalah terjadinya anomali musim, bencana alam dan kerusakan alam yang menurunkan produktivitas pertanian. Krisis pangan dunia mesti disikapi dengan peningkatan swasembada pangan guna terpenuhinya kebutuhan pangan nasional.

\section{d. Komitmen Internasional}

Kesepakatan antar negara khususnya yang telah ditandatangani (disepakati) oleh Pemerintah Indonesia perlu didukung oleh seluruh masyarakat (Pemerintah Daerah). Komitmen internasional tersebut diantaranya adalah Millenium Development Goals (MDG's) tentang paradigma pembangunan global, Protokol Kyoto tentang pengurangan emisi gas rumah kaca, Convention on the Elimination of All Form of Discrimination Against Women (CEDAW) tentang pembangunan dan pemberdayaan perempuan, Hyogo Framework tentang peredaman bencana, Ecolabelling atau sertifikasi produk dan sebagainya. Deklarasi MDGs 2015 yang ditandatangani pada tanggal 8 September 2000 menyetujui agar semua negara melaksanakan:

1. Pengentasan kemiskinan dan kelaparan yang ekstrim

Target untuk 2015:
Mengurangi setengah dari penduduk dunia yang berpenghasilan kurang dari 1 dolar AS sehari dan mengalami kelaparan.

2. Pemerataan pendidikan dasar Target untuk 2015: Memastikan bahwa setiap anak, baik laki-laki dan perempuan mendapatkan dan menyelesaikan tahap pendidikan dasar.

3. Mendukung adanya persama-an jender dan pemberdayaan perempuan

Target 2005 dan 2015: Mengurangi perbedaan dan diskriminasi gender dalam pendidikan dasar dan menengah terutama untuk tahun 2005 dan untuk semua tingkatan pada tahun 2015.

4. Mengurangi tingkat kematian anak

Target untuk 2015: Mengurangi dua per tiga tingkat kematian anak-anak usia di bawah 5 tahun.

5. Meningkatkan kesehatan ibu Target untuk 2015: Mengurangi dua per tiga rasio kematian ibu dalam proses melahirkan

6. Perlawanan terhadap HIV/AIDS, malaria, dan penyakit lainnya

Target untuk 2015: Menghentikan dan memulai pencegahan penyebaran AIDS, malaria dan penyakit berat lainnya.

7. Menjamin daya dukung 
lingkungan hidup

Target:

- Mengintegrasikan prinsipprinsip pembangunan yang berkelanjutan dalam kebijakan setiap negara dan program serta mengurangi hilangnya sumber daya lingkungan

- Pada tahun 2015 ini diharapkan mengurangi setengah dari jumlah orang yang tidak memiliki akses air minum yang sehat

- Pada tahun 2020 mendatang diharapkan dapat mencapai pengembangan yang signifikan dalam kehidupan untuk sedikitnya 100 juta orang yang tinggal di daerah kumuh

8. Mengembangkan kemitraan global untuk pembangunan Target:

- Mengembangkan lebih jauh lagi perdagangan terbuka dan sistem keuangan yang berdasarkan aturan, dapat diterka dan tidak ada diskriminasi. Termasuk komitmen terhadap pemerintahan yang baik, pembangungan dan pengurangan tingkat kemiskinan secara nasional dan internasional.

- Membantu kebutuhan- kebutuhan khusus negaranegara kurang berkembang, dan kebutuhan khusus dari negara-negara terpencil dan kepulauan-kepulauan kecil. Ini termasuk pembebasan-tarif dan kuota untuk ekspor mereka; meningkatkan pembebasan hutang untuk negara miskin yang berhutang besar; pembatalan hutang bilateral resmi; dan menambah bantuan pembangunan resmi untuk negara yang berkomitmen untuk mengurangi kemiskinan.

- Secara komprehensif mengusahakan persetujuan mengenai masalah utang negaranegara berkembang.

- Menghadapi secara komprehensif dengan negara berkembang dengan masalah hutang melalui pertimbangan nasional dan internasional untuk membuat hutang lebih dapat ditanggung dalam jangka panjang.

- Mengembangkan usaha produktif yang layak dijalankan untuk kaum muda

- Dalam kerja sama dengan pihak farmasi, menyediakan akses obat penting yang terjangkau di negara berkembang 
- Dalam dengan pind membangun adanya penyerapan keuntungan dari teknologi-teknologi baru, terutama teknologi informasi dan komunikasi.

\section{Tindak Lanjut dalam Pemberdayaan Masyarakat Petani Miskin}

Berdasarkan

penelitian, dengan berbagai macam sumber seperti wawancara dengan petani, kelompok tani, dinas pertanian dan beberapa stakeholders lainnya, diperoleh beberapa masukan, diantaranya

\section{a. Inovasi Teknologi Pertanian}

Dari inovasi teknologi yang telah diberikan selama kegiatan prima tani di Kelurahan Tolo Utara, beberapa masalah yang terjadi dilapangan adalah sebagai berikut :

- Terbatasnya ketersediaan bibit jagung

- Masih sulitnya memperoleh air pada akhir musim hujan,

- Konsevasi lahan pada lahan lereng belum dilakukan Upaya yang telah dilakukan untuk mengatasi masalah tersebut adalah : Untuk memenuhi kebutuhan benih jagung petani diarahkan untuk menggunakan jagung yang bersari bebas, karena selama ini petani menggunakan jagung hibrida yang hanya bisa digunakan satu kali saja. Membuat embung contoh di lokasi MP3MI Sekitar 169 ha di hulu sungai Kelara perlu dilakukan konsevasi lahan, dengan menanam tanaman tahunan.

\section{b. Inovasi Kelembagaan}

Akses informasi dan pengetahuan inovasi teknologi pertanian di kelurahan Tolo Utara mulai berjalan efektif. Kegiatan Empo Sipitangngarri merupakan wadah dan momen lokal dimanfaatkan oleh masyarakat untuk memperoleh informasi dan komunikasi teknologi. Kelompok tani prima yang dibentuk pada bulan April 2007 merupakan wadah untuk menyebarluaskan inovasi teknologi dan kelembagaan. Kelompok ini merupakan percontohan bagi kelompok lainnya di kelurahan Tolo Utara. Akses pasar input dilakukan melalui kerjasama dengan PT. Tanindo dan Syngenta. Pemasaran output pada dasarnya tidak mengalami kesulitan, namun saat panen harga jagung drastis menurun, sehingga diperlukan upaya agar aspek pemasaran output tidak mengalami kesulitan. Aspek permodalan petani masih mengalami kesulitan terutama pengadaan saprodi saat akan tanam. Beberapa masalah yang perlu upaya pemecahan, sebagai berikut:

1. Kegiatan inovasi masih kurang didukung dengan permodalan

2. Air untuk konsumsi dan Usahatani sangat terbatas

3. Alat dan mesin pertanian 
belum terealiasasi

4. Dampak kegiatan inovasi belum meningkatkan pendapatan petani secara luas

Upaya pemecahan masalah adalah penguatan modal kelompok tani, selain program pemerintah tentang bantuan benih jagung bersubsidi, juga pencairan dana pemicu untuk menumbuhkan kelompok tani. Masalah utama lahan kering adalah ketersediaan air sangat terbatas, upaya yang dapat dilakukan adalah melakukan koordinasi dengan Pemda untuk pembuatan embung-embung air. Pengadaan mesin chopper alat pencacah batang jagung. Untuk meningkatkan pendapatan petani secara luas dapat dilakukan dengan meningkatkan keterlibatan terutama pemasaran jagung secara berkelompok, merintis pemasaran gaplek, meningkatkan agribisnis cabai, memumbuhkan penangkar benih jagung terutama jagung komposit, merintis pemasaran pakan ternak, dan menggalakkan pengolahan jagung dan ubikayu.

Gapoktan ke dua adalah pengolahan pupuk organik dan pakan. Jumlah dan jenis ternak sebagai sumber bahan organik cukup banyak, jumlah ternak kuda 399 ekor, sapi 436 ekor dan kambing 189 ekor. Bila semua ternak ini berkontribusi terhadap pengolahan pupuk organik maka volume yang dihasilkan cukup besar. (Pemda Jeneponto, 2015)

\section{c. Lembaga Sarana Produksi}

Kebutuhan

herbisida/pestisida diperoleh dari kios sarana produksi dalam kelurahan atau di pasar kecamatan. Jumlah kios yang tersedia ada 5 unit tersebar pada 7 dusun/lingkungan. Kios/toko sarana produksi yang ada di Kelurahan tolo Utara hanya melayani pengadaan benih dan herbisida/pestisida. Kios sarana produksi yang ada belum menyediakan pupuk karena keterbatasan modal.

Kebutuhan inovasi

kelembagaan sarana produksi harus mengarah kepada ketepatan waktu, ketepatan jumlah dan ketepatan jenis sarana produksi. Sistem pengadaan saran produksi (benih, herbisida/pestisida, dan pupuk) yang dianjurkan adalah sebagai berikut: a) Lembaga Produksi, b) Lembaga Pasca Panen, c) Kelembagaan Pemasaran, d) Pola Kemitraan

\section{Strategi Penanggulangan Kemiskinan}

Dari hasil SWOT yang sudah di peroleh di atas, maka strategi untuk menanggulangi masalah kemiskinan diperlukan upaya yang memadukan berbagai 
kebijakan dan program pembangunan yang tersebar di berbagai sektor. Kebijakan pengentasan kemiskinan menurut Gunawan Sumodiningrat (1998) dapat dikategorikan menjadi 2 (dua), yaitu kebijakan tidak langsung, dan kebijakan yang langsung. Kebijakan tak langsung meliputi (1) upaya menciptakan ketentraman dan kestabilan situasi ekonomi, sosial dan politik; (2) mengendalikan jumlah penduduk; (3) melestarikan lingkungan hidup dan menyiapkan kelompok masyarakat miskin melalui kegiatan pelatihan. Sedangkan kebijakan yang langsung mencakup: (1) pengembangan data dasar (base data) dalam penentuan kelompok sasaran (targeting); (2) penyediaan kebutuhan dasar (pangan, sandang, papan, kesehatan, dan pendidikan); (3) penciptaan kesempatan kerja; (4) program pembangunan wilayah; dan (5) pelayanan perkreditan.

Untuk menanggulangi masalah kemiskinan harus dipilih strategi yang dapat memperkuat peran dan posisi perekonomian rakyat dalam perekonomian nasional, sehingga terjadi perubahan struktural yang meliputi pengalokasian sumber daya, penguatan kelembagaan, pemberdayaan sumber daya manusia (Sumodiningrat, 1998).
Program yang dipilih harus berpihak dan memberdayakan masyarakat melalui pembangunan ekonomi dan peningkatan perekonomian rakyat. Program ini harus diwujudkan dalam langkahlangkah strategis yang diarahkan secara langsung pada perluasan akses masyarakat miskin kepada sumber daya pembangunan dan menciptakan peluang bagi masyarakat paling bawah untuk berpartisipasi dalam proses pembangunan, sehingga mereka mampu mengatasi kondisi keterbelakangannya. Selain itu upaya penanggulangan kemiskinan harus senantiasa didasarkan pada penentuan garis kemiskinan yang tepat dan pada pemahaman yang jelas mengenai sebab-sebab timbulnya persoalan itu.

Terdapat tiga pendekatan dalam pemberdayaan masyarakat miskin:

Pertama, pendekatan yang terarah, artinya pemberdayaan masyarakat harus terarah yakni berpihak kepada orang miskin.

Kedua, pendekatan kelompok, artinya secara bersama-sama untuk memudahkan pemecahan masalah yang dihadapi.

Ketiga, pendekatan pendampingan, artinya selama proses pembentukan dan penyelenggaraan kelompok masyarakat miskin perlu

Available at: 
didampingi oleh pendamping yang profesional sebagai fasilitator, komunikator, dan dinamisator terhadap kelompok untuk mempercepat tercapainya kemandirian (Soegijoko, 1997).

\section{KESIMPULAN DAN SARAN}

\section{Kseimpulan}

Beberapa kesimpulan yang dapat ditarik berdasarkan hasil observasi dan analisis adalah sebagai berikut :

1. Umumnya Kabupaten Jeneponto memiliki kemampuan menabung sangat rendah dan pengenalan modernisasi pertanian masih sangat terbatas.

2. Kemiskinan di Kabupaten Jeneponto tidak sepenuhnya berasal dari kondisi sumberdaya alam setempat. Dalam hal tertentu, kemiskinan terjadi karena belum optimalnya fungsi pemerintahan setempat untuk memberdayakan petani setempat

(kemiskinan struktural).

3. Dari hasil wawancara dan data primer diketahui bahwa sebagian besar produk pertanian yang digunakan untuk memenuhi kebutuhan rumah tangga. Pola demikian menyebabkan pertumbuhan ekonomi di desa sampel berjalan sangat lambat. Sangat rendahnya tingkat tabungan menyebabkan kemampuan melakukan investasi sangat terbatas dan akibat lebih lanjut, produktivitas tenaga kerja juga rendah.

4. Di Kabupaten Jeneponto diketahui bahwa terdapat variasi kepemilikan SDA, namun masing-masing masih memiliki peluang berkembang sesuai dengan potensi kandungan SDA-nya. Salah satu bentuk pengembangannya adalah dengan sistim agribisnis yang bertumpu pada kekuatan petani (padat karya), atau tidak dilakukan sepenuhnya dengan pola padat modal. Hal ini dimaksudkan agar tenaga kerja setempat dapat dimanfaatkan semaksimal mungkin sehingga nilai tambah dan multiplier effect-nya benarbenar dapat dinikmati penduduk setempat. Di samping itu alternatif lain yang tepat untuk diterapkan dalam kerangka memanfaatkan SDA yang terbatas adalah dengan melakukan diversifikasi tanaman pertanian dan perkebunan yang bernilai ekonomis tinggi sebagai sumber penghasilan keluarga.

\section{Saran}

Seyogyanya pendekatan yang dilakukan dalam menyusun program kebijakan adalah bottom up. Pendekatan bottom up didasarkan pada pemahaman bahwa usulan dari kalangan bawah (dalam hal ini 


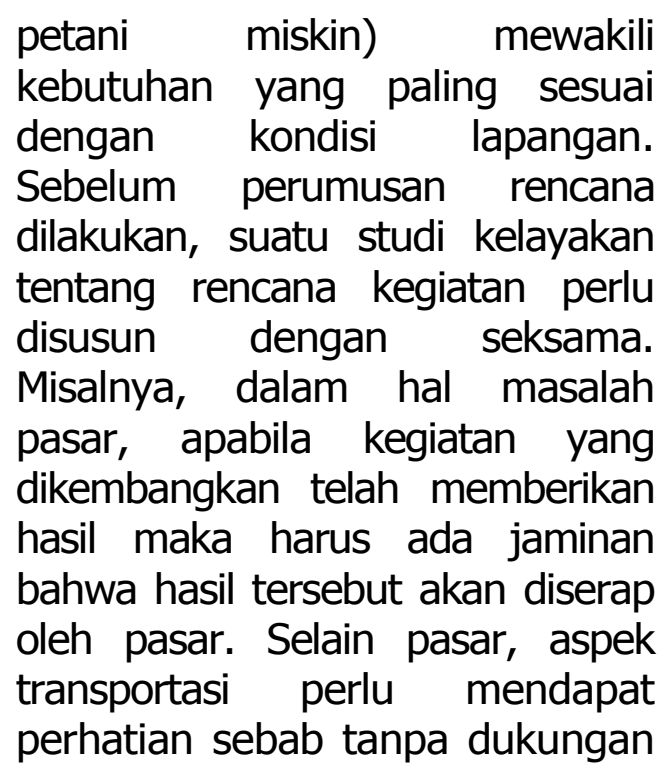

transportasi maka produksi cenderung akan merugi. Selanjutnya, transportasi ini perlu mendapat dukungan dari kondisi jalan, jembatan, dan lain-lain.

\section{DAFTAR PUSTAKA}

Hikmat, H. (2004). Strategi Pemberdayaan Masyarakat. Bandung: Humaniora Bandung.

Smith, M. P. (2003). Pembangunan Ekonomi Di Dunia Ketiga. Jakarta: Erlangga. 